\title{
Analysis of Impact Assessment Practice and Mitigation for Shipping Activity in the Eastern Canadian Arctic
}

\author{
Bethany Thiessen, ${ }^{1}$ Bram Noble ${ }^{1,2}$ and Kevin Hanna ${ }^{3}$
}

(Received 11 October 2019; accepted in revised form 20 March 2020)

\begin{abstract}
Marine traffic is increasing in the Canadian Arctic, largely because of changing ice conditions, a growing tourism industry, and natural resource extraction. Impact assessment (IA) is a primary instrument for managing the impacts of project development in the Arctic, but there has been limited analysis of the scope and application of IA for identifying and managing the impacts of shipping. This paper examines the impacts of shipping activity associated with mining projects in the eastern Canadian Arctic, including barge traffic and resupply vessels; the mitigation actions commonly prescribed in IA; and the key IA challenges facing decision-makers. Results show 71 impacts that may be considered common to IA applications for shipping, for which the mitigation strategies rely heavily on compliance-based measures and "best" practices to either minimize or avoid impacts, supported by follow-up programs that provide for adaptation of mitigation based on monitoring results. However, results also illustrate concerns over the ability of IA to effectively manage the cumulative effects of increasing Arctic marine traffic. Only a minority of projects involving marine transport trigger IA, even though other types of marine traffic, such as tourism, may generate similar types of impacts. The common impacts and mitigation solutions identified in this research and the lessons from monitoring can inform future IAs for shipping, improve permitting processes for shipping activities that do not require IA, and provide a foundation for a more regional or sector-wide approach to identifying and mitigating the cumulative effects of increasing vessel traffic.
\end{abstract}

Key words: impact assessment; marine environments; Arctic shipping; mitigation; Nunavut Settlement Area

RÉSUMÉ. Dans l'Arctique canadien, le trafic maritime augmente, principalement en raison des conditions changeantes de la glace, de la croissance de l'industrie du tourisme et de l'extraction des ressources naturelles. Les évaluations environnementales (EE) constituent un des principaux outils de gestion des incidences de la mise en valeur de projets dans l'Arctique. Toutefois, il existe peu d'analyses sur le rôle de la portée et de l'application des EE dans la détermination et la gestion des incidences de la navigation maritime. Cet article examine les incidences de la navigation maritime liée aux projets d'exploitation minière dans l'est de l'Arctique canadien, ce qui touche la circulation de barges et de navires de ravitaillement; les mesures d'atténuation couramment prescrites dans les EE; et les principaux défis auxquels les preneurs de décisions font face en matière d'EE. Selon les résultats, il y a 71 incidences susceptibles d'être considérées comme communes aux applications d'EE en matière de navigation maritime, pour lesquelles les stratégies d'atténuation dépendent beaucoup de mesures de conformité et de mesures « exemplaires » pour minimiser ou éviter les incidences, ces stratégies étant appuyées par des programmes de suivi qui prévoient l'adaptation des résultats de surveillance fondés sur l'atténuation. Cependant, des inquiétudes en rapport avec la capacité des EE à bien gérer les effets cumulatifs de l'accroissement du trafic maritime dans l'Arctique se dégagent aussi des résultats. Seulement une minorité de projets faisant appel au transport maritime déclenchent la tenue d'EE, même si d'autres types de navigation maritime, comme celle liée au tourisme, peuvent engendrer des incidences semblables. Les incidences communes et les solutions d'atténuation présentées dans cette recherche, de même que les leçons tirées de la surveillance, peuvent éclairer les EE à venir en matière de transport maritime, améliorer les processus d'établissement de permis pour les activités de transport qui n'exigent pas d'EE, et servir de fondement à une approche plus régionale ou sectorielle visant à déterminer et à atténuer les effets cumulatifs de l'augmentation du trafic maritime.

Mots clés : évaluation environnementale; environnements maritimes; navigation maritime dans l'Arctique; atténuation; région du Nunavut

Traduit pour la revue Arctic par Nicole Giguère.

\footnotetext{
${ }^{1}$ Department of Geography and Planning, University of Saskatchewan, Saskatoon, Saskatchewan S7N 5C8, Canada; beth.thiessen@usask.ca

${ }^{2}$ Corresponding author: b.noble@usask.ca

${ }^{3}$ Centre for Environmental Assessment Research, The University of British Columbia, Fipke Centre for Innovative Research, Kelowna, British Columbia V1V 1V7, Canada; kevin.hanna@ubc.ca

(C) The Arctic Institute of North America
} 


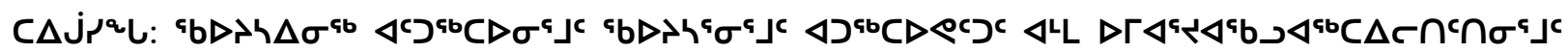 ba ${ }^{\circ} a^{a} L \sigma$ baCr $\triangle P D C C^{c b} \Gamma$}

\section{$\Delta$ CLCSDRC}

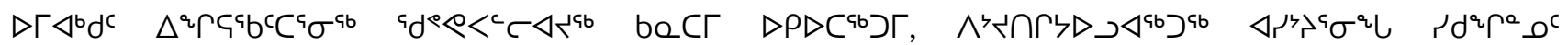

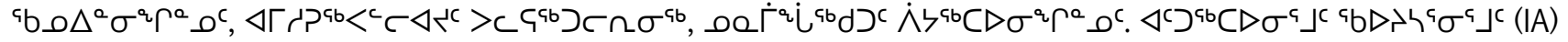

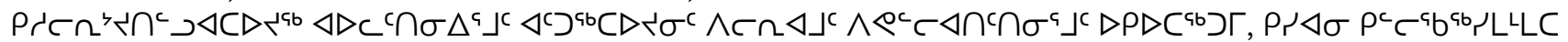

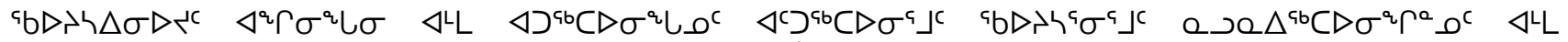

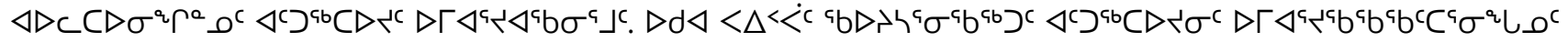

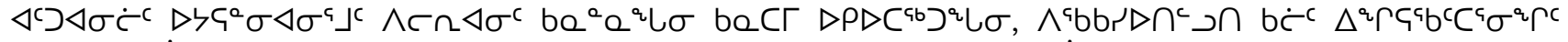

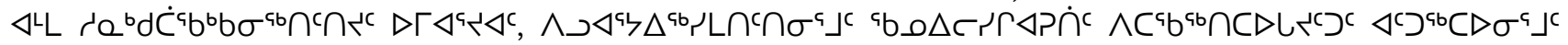

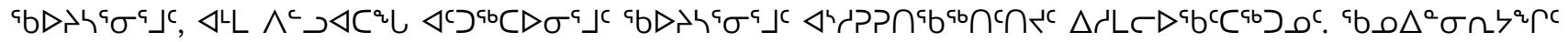

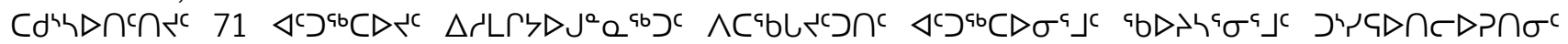

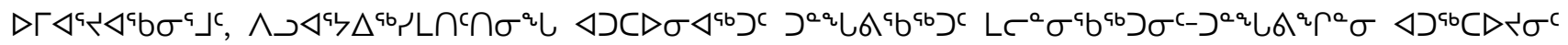

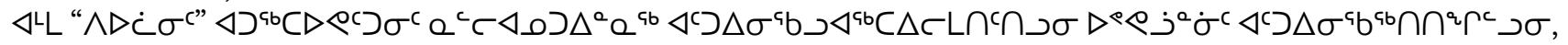

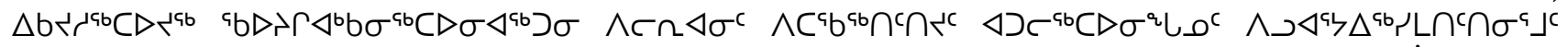

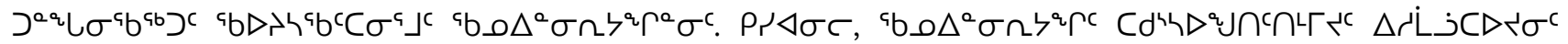

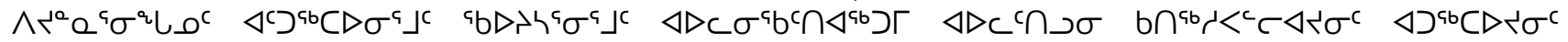

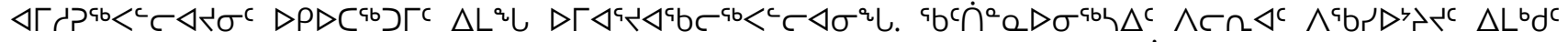

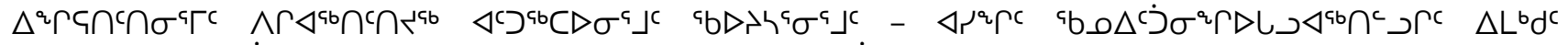

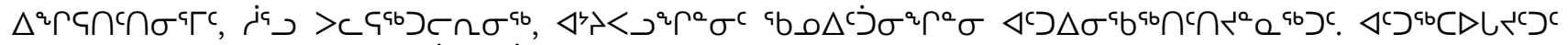

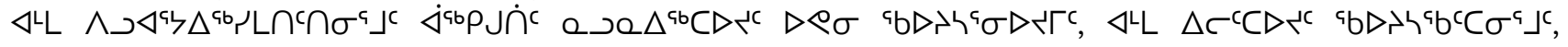

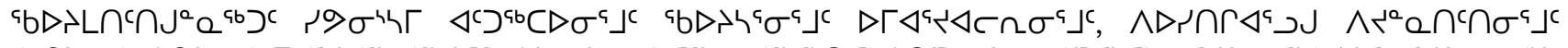

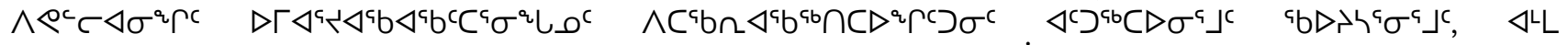

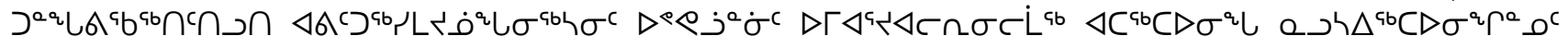

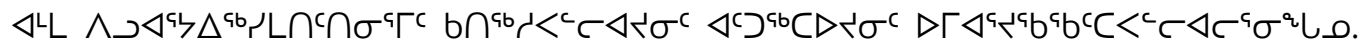

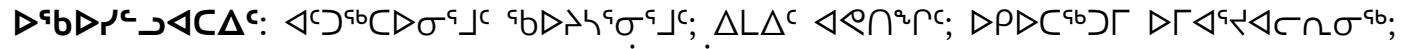

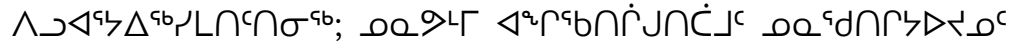

\section{INTRODUCTION}

Arctic environments are experiencing rapid environmental and social change. Pressures arise from population growth, resource development, tourism, and changing political relationships (Arctic Council, 2016). Climate change plays a significant role in a changing Arctic environment, with declining sea ice cover, lessening snow cover extent and depth, thawing permafrost, as well as changes in species distributions in terrestrial and aquatic environments (Larsen et al., 2014; McWhinnie et al., 2018). Some of the strongest negative trends in sea ice extent and volume in the Canadian Arctic are in Hudson Bay and Baffin Bay, both of which are regions with heavy shipping activity (Dawson et al., 2018). Changes in sea ice and climatic conditions may have implications for shipping and opportunities related to international trade (Stephens, 2016), natural resource development (Têtu et al., 2015), and tourism (Lasserre and Têtu, 2015).

Dawson et al. (2018) found that vessel traffic nearly tripled between 1990 and 2015 across the Canadian Arctic, which is defined as the Northern Canada Vessel Traffic Services Zone (Minister of Justice, 2010). Arctic communities have a different relationship to shipping than coastal communities in southern Canada, since many depend on shipping to meet their most basic needs for goods, services, and energy supply. This reliance has profound repercussions for the availability and prices of food, construction materials, housing, and fuel for electricity, heating, and transportation (Prowse et al., 2009; Brooks and Frost, 2012; CCA, 2017). In addition to community resupply, many other types of vessels operate in the Canadian Arctic: government and research vessels, general cargo ships, bulk carriers, tanker ships, passenger ships, pleasure crafts, tugs and barges, fishing vessels, and oil and gas exploration vessels (Pizzolato et al., 2014; Dawson et al., 2017). The largest portion of the increase in traffic comes from general cargo and government icebreakers, including research ships, while the fastest growing segment is pleasure crafts (or non-commercial tourism). Spatially, changes in traffic have favoured areas with active land-based mineral exploration and development sites (Dawson et al., 2018).

The possibility and reality of increased Arctic shipping raise important questions for local communities, governments, and industry concerning the impacts to both natural and human environments (Têtu et al., 2015; McWhinnie et al., 2018). Arctic shipping comes with its own unique set of challenges: the seasonality of routes, the presence of ice hazards, climate variability, requirements for specific equipment, the availability of bathymetric and navigational data, and the availability of and proximity 
to emergency response capabilities (CCA, 2016; Guy and Lasserre, 2016). Vessels and shipping activity and associated infrastructure in the Arctic are highly regulated through a range of international agreements, as well as federal and territorial legislation and regulations (VanderZwagg et al., 2008; Chircop, 2009; Dawson et al., 2017). The increase in shipping activity across the Arctic, from tourism to re-supply for communities and industrial developments, places increased pressure on the regulatory and planning environment to identify potential impacts associated with shipping activity and manage this change.

Impact assessment (IA), also referred to as environmental assessment or environmental impact assessment, is one of the primary regulatory, planning, and decision-support tools used across the Arctic to assess, mitigate, and monitor the impacts of development activities (Koivurova, 2008; Noble and Hanna, 2015). The basic intent of IA is to identify the likely significant environmental and social impacts of a proposed action, determine appropriate mitigation responses, and provide an opportunity for public comment before decisions are made regarding those actions (Morgan, 2012). In the Canadian Arctic there is a mix of territorial IA (e.g., Yukon Environmental and Socio-economic Assessment Act) and systems that have developed from the settlement of comprehensive Indigenous land-claim agreements, administered under regional co-management boards (e.g., Mackenzie Valley Environmental Impact Review Board, Western Arctic Environmental Screening Committee and Environmental Impact Review Board, Nunavut Impact Review Board).

Most shipping activities in the Canadian Arctic do not trigger IA reviews. In the eastern Canadian Arctic, for instance, a shipping activity is subject to review through the IA process only if it is part of a land-based project (Barry et al., 2016). Triggering an IA can also depend on who is undertaking the activity. For example, a barge carries cargo and fuel for community resupply to Rankin Inlet, Nunavut, during the open-water season; this type of shipping is not subject to an IA screening to determine if a more comprehensive assessment is required beyond the usual needed permits to operate a sealift. The same barge could be contracted to supply the Meliadine gold mine in Nunavut with cargo and fuel, using the same route and harbour facilities; this type of shipping would undergo an IA, but only as part of the land-based project authorization. Tourism operations and research vessels can trigger an IA screening process, but are not typically subject to a full IA (Thiessen, 2019). The number of shipping activities subject to a comprehensive IA for environmental, social, and cumulative impacts is thus low compared to total vessel traffic.

Notwithstanding the increase in shipping activity in the Arctic and the importance of IA as a public review process for identifying and managing impacts, there has been limited analysis of the types of impacts and mitigations addressed in IAs for shipping activity. While studies exist on shipping in the Canadian Arctic (Prowse et al., 2009; Pizzolato et al., 2014; Stewart et al., 2015; Têtu et al., 2015;
Guy and Lasserre, 2016; Dawson et al., 2018; McWhinnie et al., 2018), the role of IA in Arctic shipping has received minimal attention. Understanding industry practice has historically played a critical role in advancing the knowledge base necessary to build international standards (VanderZwagg et al., 2008). In this paper, we identify the routine impacts of Arctic shipping that are considered in IA and explore the management approaches adopted in project design, mitigation, and follow-up. In doing so, there is an opportunity to discover transferable lessons for managing impacts across IA practice and to inform best management practices for those shipping activities that are not subject to full IA but are likely to generate similar impacts.

\section{STUDY AREA AND METHODS}

The Nunavut Settlement Area (NSA) (Fig. 1), a region highly dependent on the marine environment for travel, hunting, harvesting, recreation, livelihoods, health, and cultural values, has seen shipping traffic double between 1990 and 2015 (Dawson et al., 2017). The shipping operations of projects in the NSA that have undergone an IA by the Nunavut Impact Review Board (NIRB) were the focus of this research. The marine environment is an important connector for Inuit and Nunavummiut (residents of Nunavut). Of the 25 communities in Nunavut, all but one are coastal and all are only connected by air and sea (Dawson et al., 2017). While sea ice has been a barrier to shipping in the region, it is an important avenue for the mobility of communities (Olsen et al., 2019). Recent studies by Têtu et al. (2015) and McWhinnie et al. (2018), to name just a few, have noted increasing concerns of local communities about the impacts of increased shipping activity and pollution on marine environments at local and regional scales.

The NSA was established through the signing of the Agreement Between the Inuit of the Nunavut Settlement Area and Her Majesty The Queen in Right of Canada (Nunavut Agreement) (Canada and Tunngavik Federation of Nunavut, 1993), a comprehensive land claim that led to the creation of the territory of Nunavut in 1999. "Land" in the Nunavut Agreement (1993, Article 3) includes freshwater and marine areas in the NSA. The process of settling land claims created what Wenzel (2004) calls "two Nunavuts": one created by the Nunavut Agreement and the other, the territory and political unit of Nunavut, through the division of the Northwest Territories. The Nunavut Agreement fundamentally recognized Inuit title and the right to use and make decisions about land and resources within the NSA (Barry et al., 2016). This trajectory makes Nunavut's regulatory environment unique in Canada. Nunavut has a public government created to infuse Inuit culture and values within the workings of a system that bears the hallmarks of Western style governance, for a region where $85 \%$ of the population is Inuit (Statistics Canada, 2017). 


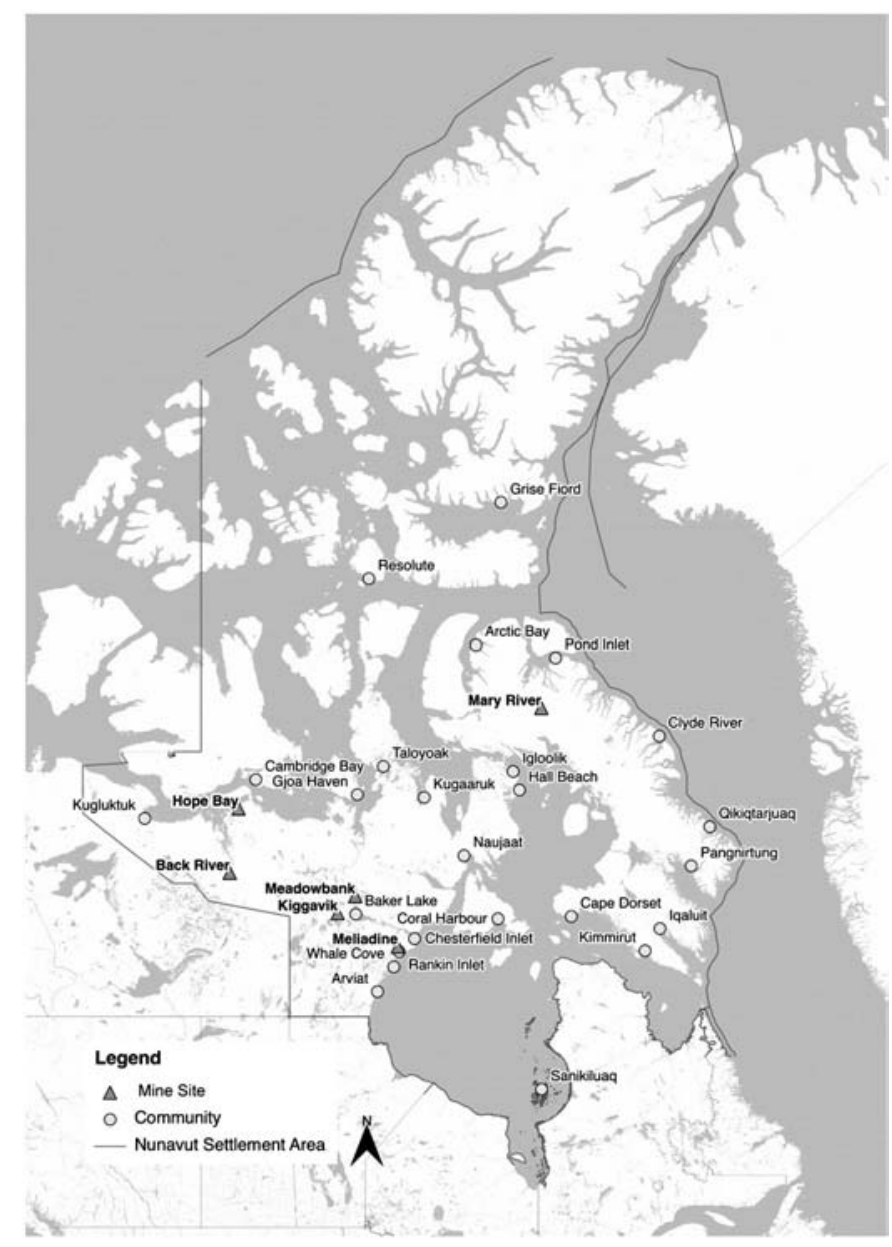

FIG. 1. Nunavut Settlement Area with locations of communities and mining projects with a shipping component.

Nunavut's integrated resource management system involves institutions of public governance or co-management boards that are responsible for the management of water and wildlife, land use planning, IA, and surface rights. The NIRB is the co-management board responsible for conducting IAs of project proposals within the NSA, including the marine environment. The NIRB's purpose - to protect and promote the existing and future well-being of Nunavummiut and the ecosystemic integrity of the NSA - was established in the Nunavut Agreement (1993, Article 12.2.5) while the Nunavut Project Planning and Assessment Act (NuPPAA, 2013) realizes the "onewindow approach" to land and resource management as envisioned under the agreement. Under NuPPAA, the NIRB receives project referrals from the Nunavut Planning Commission where projects are assessed for their conformity to regional land use plans, if such plans have been established (Barry et al., 2016; NPC, 2016). The NIRB can also receive referrals from Parks Canada when, for example, a cruise ship seeks passage through a marine protected area or access to a national park. This example marks a critical distinction for shipping activities: for shipping to trigger an IA screening process, it must include a land-based activity that requires authorization, such as national park access or a mining operation including shipping.

Once a referral is received, NIRB screens the application and determines if an IA review is required based on whether the project may have significant adverse ecosystemic or socioeconomic effects, significant adverse effects on wildlife habitat or Inuit harvesting activities, or cause significant public concern (NuPPAA, 2013, section 89(1)). Marine activities such as tourism or scientific research vessels are considered "projects" and screened by the NIRB; however, these types of activities typically do not require an IA and are referred to various territorial or federal authorizing agencies for applicable permitting. If an IA review is necessary, the terms of reference are set in a scoping phase during which ecological and socioeconomic valued components (VCs) are selected, baseline conditions for biophysical and human environments are described, project activities and components are assessed for their potential impacts on VCs, impact predictions are made, mitigation measures identified, and potential residual impacts are evaluated for their significance. A project's proponent prepares the environmental impact statement (EIS). The NIRB then conducts public and technical reviews of the EIS, which includes a final public hearing. The NIRB then makes a recommendation to the responsible federal minister on whether the project should proceed and, if so, the terms and conditions of the project's certificate. All project documents and correspondences from the time the screening application is received through postcertificate monitoring or amendments are posted online through the NIRB's Public Registry (Public Registry, n.d.).

In this co-managed process, intervenors or participants include federal and territorial authorizing agencies, organizations and individuals representing Inuit as rights holders, hamlet representatives, the public, and non-governmental or transboundary groups (NIRB, 2018d). NIRB's process aims to create opportunities for rights holders to participate in decision making and, importantly, to consider Inuit Qaujimajatuqangit and Inuit Qaujimaningit (collectively IQ) in the IA process (Gondor, 2016). IQ encompasses a body of knowledge, worldviews, cosmology, experiences, and values rooted in the daily life of the Inuit across Inuit Nunangat (homeland) and guides "how to live a good life" (Karetak and Tester, 2017:3), beyond a narrow conception of traditional knowledge (TK) (Tester and Irniq, 2009; Barry et al., 2016; Egede Dahl and Hansen, 2019). This distinction is important in Nunavut (Wenzel, 2004; Lévesque, 2015); before the creation of the territory, there was a desire to develop an Inuktitut term to acknowledge that Inuit TK encompassed far more than what Western science understands about TK (Usher, 2000; Stevenson, 2006; White, 2006) and to integrate the breadth of Inuit culture into bridging the two Nunavuts. In IAs, the NIRB uses the guiding principles of IQ developed by the Government of Nunavut (GN, n.d.). Proponents are required to not only incorporate IQ into baseline studies but to demonstrate in their EIS how the effects assessment, 
TABLE 1. Projects selected for document review.

\begin{tabular}{|c|c|c|c|c|}
\hline $\begin{array}{l}\text { Certificate number } \\
\text { and date }\end{array}$ & $\begin{array}{l}\text { Project name and } \\
\text { NIRB reference number }\end{array}$ & Project type & $\begin{array}{l}\text { Proposed number of vessel } \\
\text { transits during operation/year }\end{array}$ & ${ }^{1}$ Shipping and infrastructure component \\
\hline $\begin{array}{l}\# 004 \\
2006\end{array}$ & $\begin{array}{l}\text { Meadowbank Gold Project } \\
\text { 03MN107 }\end{array}$ & Gold mine & $5-10$ vessels & $\begin{array}{l}\text { Open-water resupply. } \\
\text { Dock facilities in Baker Lake. }\end{array}$ \\
\hline $\begin{array}{l}\# 005 \\
2012\end{array}$ & $\begin{array}{l}\text { Mary River } \\
08 \mathrm{MN} 053\end{array}$ & Iron mine & $\begin{array}{l}102 \text { ore carriers } \\
\text { (year-round, Steensby) } \\
6-9 \text { cargo/fuel } \\
\text { (seasonal, Milne) }\end{array}$ & $\begin{array}{l}\text { Original application: open-water resupply from } \\
\text { Milne Port (north of the mine site), and year-round } \\
\text { shipping of ore with icebreaking vessels from } \\
\text { Steensby Port (south of the mine site). }\end{array}$ \\
\hline $\begin{array}{l}\text { \#005 Amendment } \\
2014\end{array}$ & $\begin{array}{l}\text { Mary River } \\
08 \mathrm{MN} 053 \\
\text { Phase } 1 \text { of Early Revenue } \\
\text { Phase (ERP) }\end{array}$ & Iron mine & $\begin{array}{l}54 \text { ore carriers } \\
\text { (seasonal, Milne) }\end{array}$ & $\begin{array}{l}\text { Phase development application: open-water shipping } \\
\text { of ore from Milne Port. }\end{array}$ \\
\hline $\begin{array}{l}\# 006 \\
2015\end{array}$ & $\begin{array}{l}\text { Meliadine } \\
11 \mathrm{MN} 034\end{array}$ & $\begin{array}{l}\text { Gold mine; } \\
\text { open-water resupply }\end{array}$ & $5-8$ cargo; $4-6$ fuel & $\begin{array}{l}\text { Open-water resupply. } \\
\text { Port facilities in Melvin Bay near Rankin Inlet } \\
\text { (existing). }\end{array}$ \\
\hline $\begin{array}{l}\# 007 \\
2017\end{array}$ & $\begin{array}{l}\text { Back River Project } \\
\text { 12MN036 }\end{array}$ & $\begin{array}{l}\text { Gold mine; } \\
\text { open-water resupply }\end{array}$ & 10 vessels & $\begin{array}{l}\text { Open-water resupply. } \\
\text { Bathurst Inlet dock facilities (new). }\end{array}$ \\
\hline $\begin{array}{l}\text { Certificate refused } \\
2016\end{array}$ & $\begin{array}{l}\text { Kiggavik } \\
09 \text { MN003 }\end{array}$ & $\begin{array}{l}\text { Uranium mine; } \\
\text { open-water resupply }\end{array}$ & Maximum 31/year & $\begin{array}{l}\text { Open-water resupply. } \\
\text { Dock facilities in Baker Lake (new). }\end{array}$ \\
\hline $\begin{array}{l}\# 008 \\
2016\end{array}$ & $\begin{array}{l}\text { Whale Tail Pit - } \\
\text { Meadowbank Gold Project } \\
\text { 16MN056 }\end{array}$ & $\begin{array}{l}\text { Gold mine; } \\
\text { open-water resupply }\end{array}$ & $3-6$ vessels & $\begin{array}{l}\text { Open-water resupply. } \\
\text { Dock facilities in Baker Lake (existing). }\end{array}$ \\
\hline $\begin{array}{l}\# 009 \\
2018\end{array}$ & $\begin{array}{l}\text { Phase } 2 \text { Hope Bay (expansion } \\
\text { to Doris North Gold Mine, } \\
\text { Certificate \#003) } \\
\text { 12MN001 }\end{array}$ & $\begin{array}{l}\text { Gold mine; } \\
\text { open-water resupply }\end{array}$ & $6-7$ vessels & $\begin{array}{l}\text { Open-water resupply. } \\
\text { Roberts Bay dock facilities (existing and new). }\end{array}$ \\
\hline Proposed total trans & ts: 243 vessels/year & & & \\
\hline
\end{tabular}

${ }^{1}$ As proposed and reported in each project's environmental impact statement or the final public hearing report, all available through the NIRB's Public Registry

mitigation or management measures, and monitoring employ IQ values.

\section{Data Collection and Analysis}

Our method and approach involved a document review of a sample of completed IAs between 2006 and 2018 and focus groups with NIRB members. The purpose of the document review was to identify the impacts of Arctic shipping routinely considered in IA and how those impacts are managed. The focus groups were used to validate the findings of the document review, to supplement information reported in the public IA record, and to provide an institutional perspective on how the NIRB makes decisions in IAs. Two focus groups were held in Cambridge Bay, Nunavut in July 2018: one with 10 members of the NIRB's technical and executive staff and another with the eight sitting board members (full representation at the time).

The sample of IAs was selected based on inclusion criteria: 1) the status of a completed review, 2) the involvement of a shipping component or marine infrastructure such as a dock or port in the project, and 3) the availability of documents on the NIRB's Public Registry (Table 1). Using the registry, only mining projects had undergone an IA by the NIRB as of 2018. Of the completed IAs, all involved a shipping component, but the Jericho Project and Doris North Mine were excluded from the analysis because of the limited availability of documents at the time of this research. Eight IAs for six mines with a shipping component were identified (including one amendment and one expansion to existing projects). One project, the Mary River iron ore mine, involves the year-round shipping of ore concentrate destined for European markets, as well as cargo and fuel, while the remaining five projects move gold (or, in the case of Kiggavik, proposed to move uranium) by air and involve the seasonal resupply of cargo and fuel (open-water shipping only). Based on the proposed number of transits (Table 1), collectively these six mines could account for approximately 243 vessel trips per year, assuming some overlap in project operational phases. Proponents did not present annual transits in kilometres traveled, so it is unclear how many kilometres these projects could account for in total annual kilometres travelled by all vessels in the NSA. The documents reviewed for each IA were sections of the final EIS, including the marine environment chapter, cumulative effects chapter, shipping management plans, and the final public hearing report. A total of 70 documents were reviewed across the sample of IAs. 
The first round of coding of IA documents and focus group transcripts was completed in NVivo 12. Summary tables presented in EIS were used as a starting point to identify shipping impacts and mitigation measures. Impacts in IA documents are often obscured by the sheer volume of information presented (i.e., each chapter of an EIS can be hundreds of pages). The first round of coding yielded 543 potential impacts of shipping and 428 proposed mitigation measures. These codes were then organized into a matrix, where additional details not reported in the summary tables were added to identify the project activity or effect pathway, the potential effect, the VCs affected, and possible mitigation measures. Mitigation measures were classified based on the mitigation hierarchy (Tinker et al., 2005; Larsen et al., 2018): avoid, minimize, and compensate. Routine impacts and their corresponding mitigation measures were defined as those common to at least three projects. A limitation of this approach is that identifying impact statements and proposed mitigation measures is not indicative of actual outcomes or effectiveness of mitigation, which can only be verified through monitoring.

Public hearing reports were reviewed to gain an understanding of the NIRB's approach to assessing and managing projects with a shipping component in advance of the focus groups. Public hearings are enabled under the Nunavut Agreement (1993: Article 12.2.24) and NuPPAA (2013: section 26) and intended to balance the requirements of natural justice, procedural fairness, and legal powers (such as the ability to subpoena witnesses), while emphasizing flexibility and informality. Public hearings are not bound by the same rules as court proceedings and acknowledge Inuit traditions of oral communication and decision-making (NIRB, 2018d). Summary reports prepared by the NIRB after the public hearing provided additional context and explanation of the NIRB's approach to impact management based on the findings of the EIS, the technical review, and the perspectives of affected communities. Emergent themes from the analysis of impacts and mitigation and the context provided by the hearing reports informed the focus group discussions. Focus group transcripts were then coded to allow for critical reflection of the themes that emerged from the IA documentation (Richards and Morse, 2013).

\section{RESULTS}

\section{Potential Impacts of Shipping}

The selection of marine VCs was similar across all eight IAs, including marine water quality, marine fish and fish habitat, and marine mammals. Indicator species varied depending on the local and regional study areas; ringed seals were the only common mammal across all IAs. Marine sediment quality and marine birds were assessed in seven of the eight IAs, although birds were assessed as part of the terrestrial environment in the eighth assessment.
Sea ice was only assessed for Mary River, the only project that involved year-round shipping and icebreaking. For socioeconomic VCs, the terminology and organization of the human environment chapters varied across projects but common VCs relevant to the marine environment included country foods, resource and land-use, and Inuit harvesting activities.

A total of 543 potential impacts of shipping and 428 proposed mitigation measures were identified from the sample of IA documents. Often, mitigation measures were presented as addressing multiple impacts. After duplicates were removed, and impacts were organized by $\mathrm{VC}$ and any corresponding mitigation, 331 potential impacts were identified. A total of 71 biophysical impacts were considered routine (i.e., common to at least three projects). However, there were only a few routine impacts identified to the human environment. Given the inclusion criteria, impacts to the biophysical and human environments do not include effects or pathways associated with yearround shipping such as icebreaking since only one project involved these activities.

Table 2 shows the potential, routine biophysical impacts of Arctic shipping in the NSA along with the common mitigation measures for each impact or group of impacts. Where VCs are grouped, such as water quality and sediment quality, some projects assessed these VCs together and some separately. The impacts and mitigation measures assessed separately were often the same for both components, so they are presented together in Table 2. Multiple effects listed for a VC were counted individually rather than by project activity or causal factor, which yielded a total of 71 potential impacts.

Typical project activities that were assessed included construction activities for in-water and supporting infrastructure; project footprints from infrastructure and the shipping route; routine shipping activities such as ballast water exchange, fuel transfers, and discharges; site discharge and contact water; and accidents and malfunctions such as fuel spills or grounding events. Proponents were also required to consider transboundary effects where applicable, cumulative effects, and climate change in their impact statements.

Only two impacts to the human environment from shipping activities were considered routine (i.e., common to at least three projects) across the sample of IA documents. This result is likely because of how human VCs are selected, the differences between and within regions and communities, and the differences in how each proponent approached the assessment. Since the shipping components were part of a mining proposal, much of the human environment chapters focused on the effects of resource development. Unlike biophysical impacts, the social, cultural, and economic impacts of shipping activities were often specific to the context of each local community and environment. VCs ranged from marine resources such as country foods or materials for arts and crafts like soapstone; Inuit harvesting activities including hunting, fishing, and 


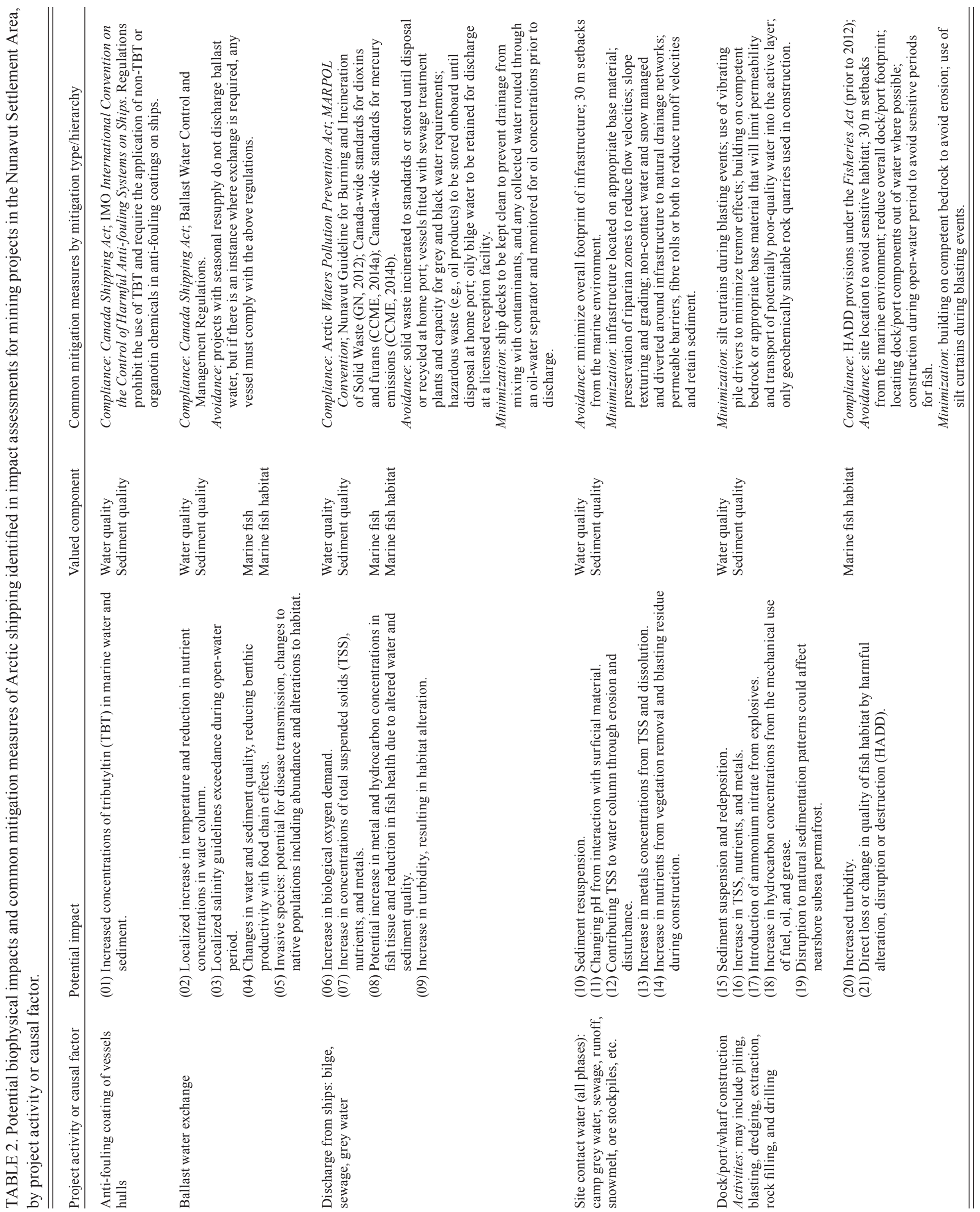




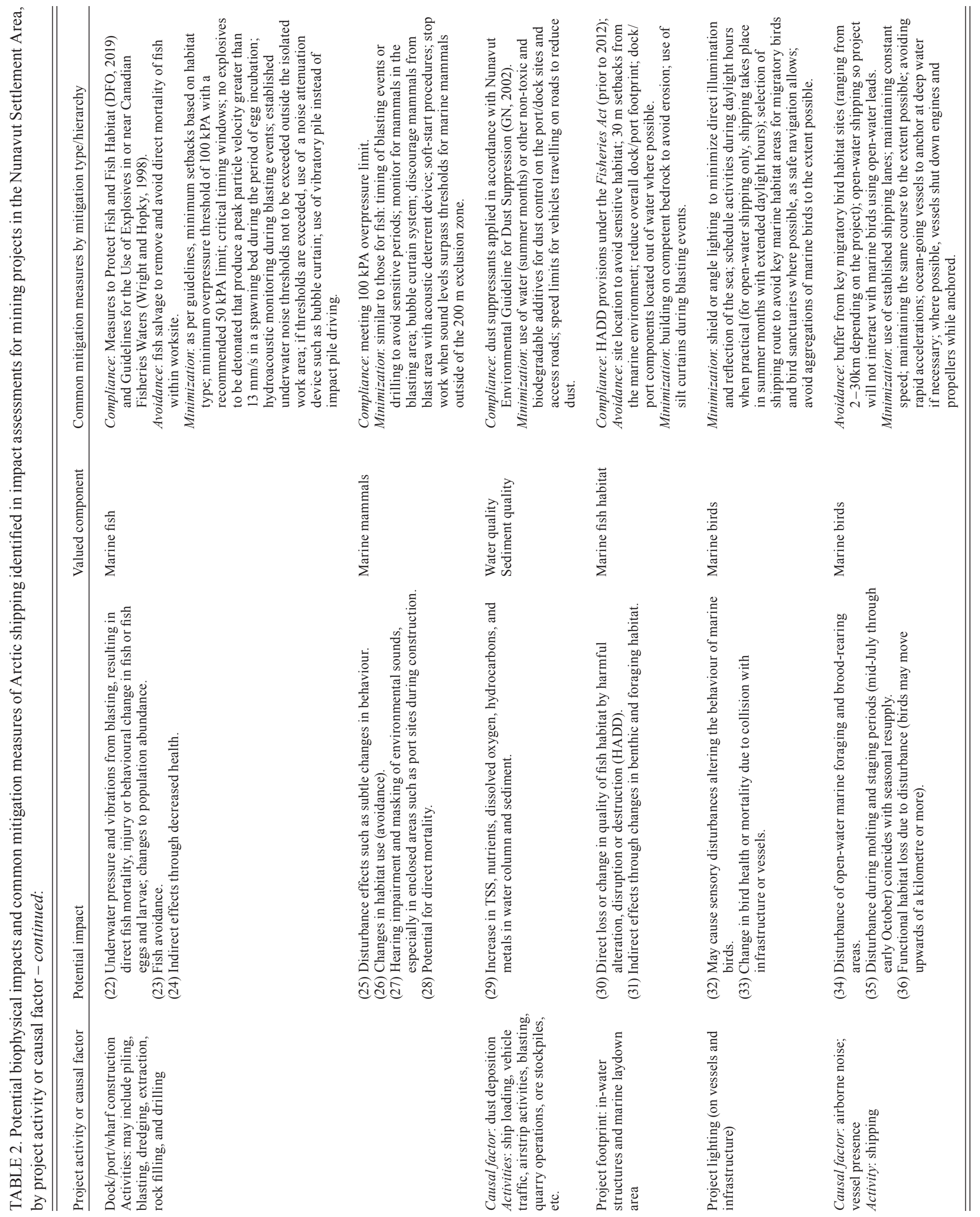




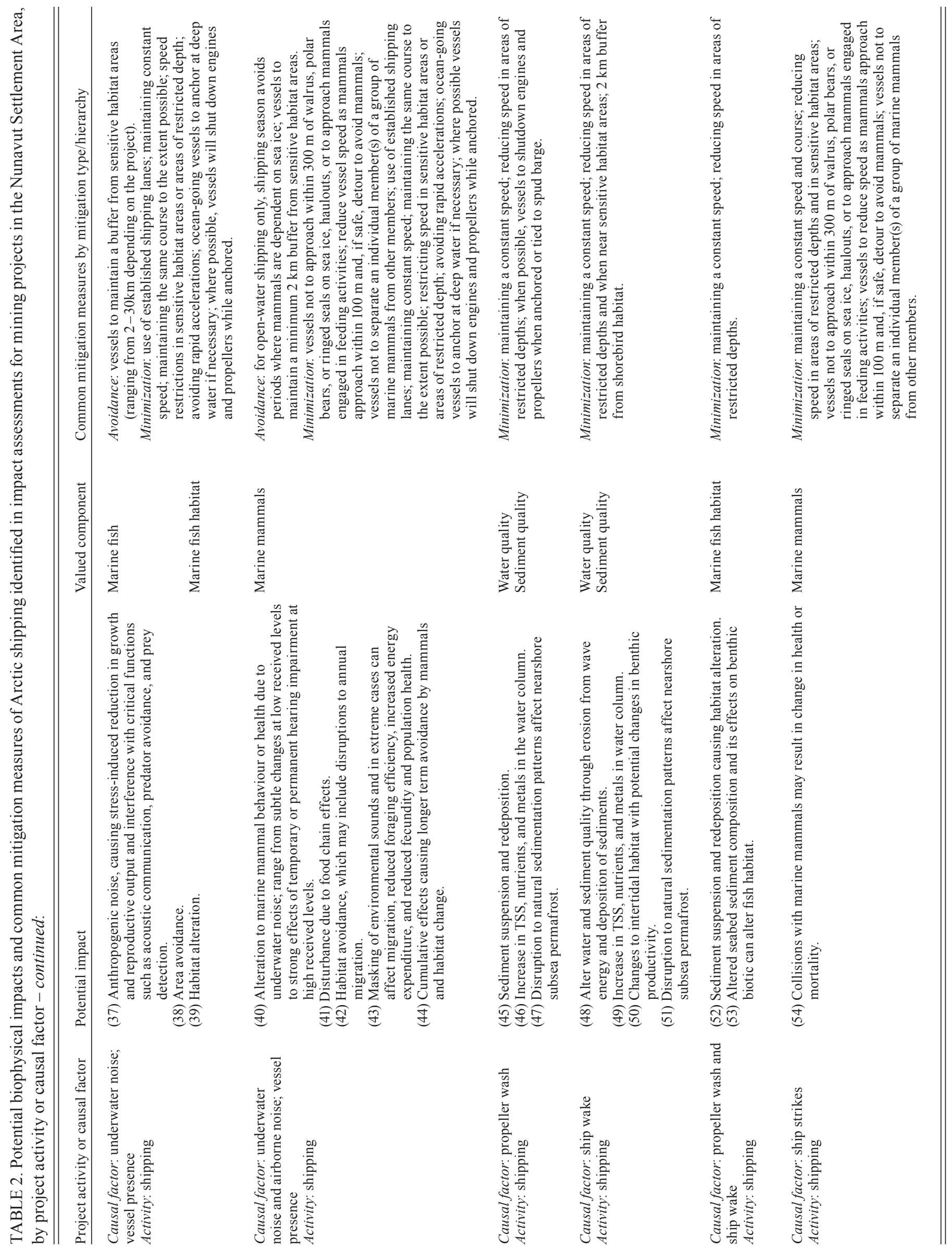




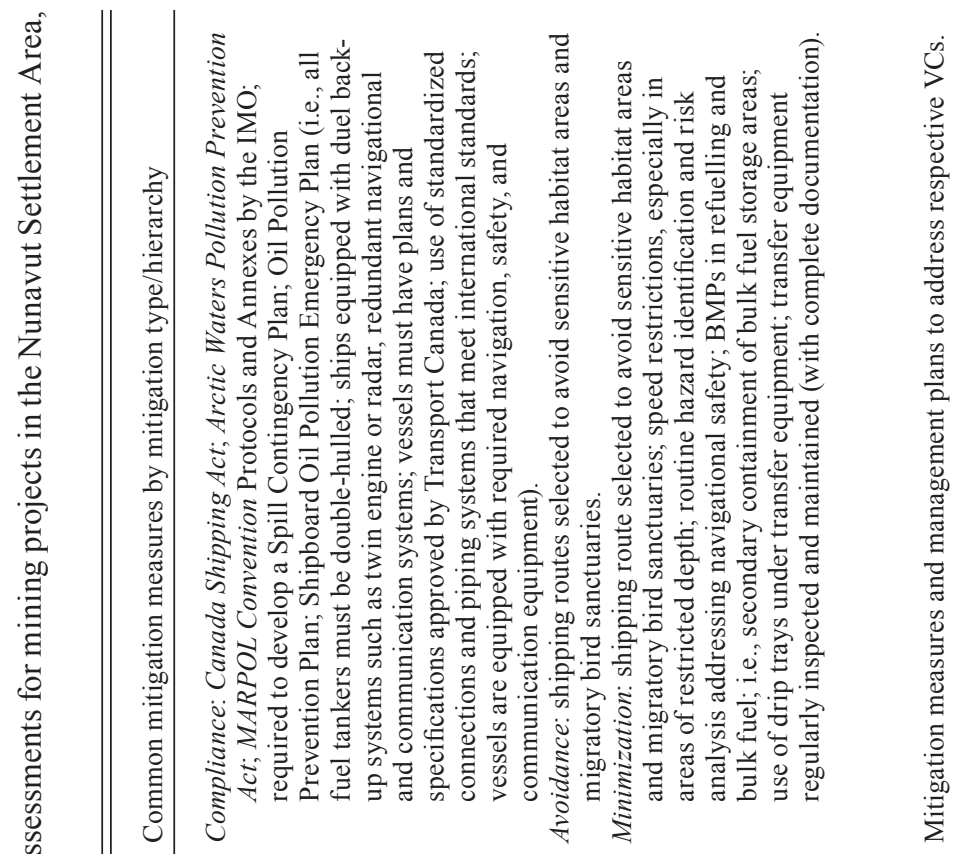

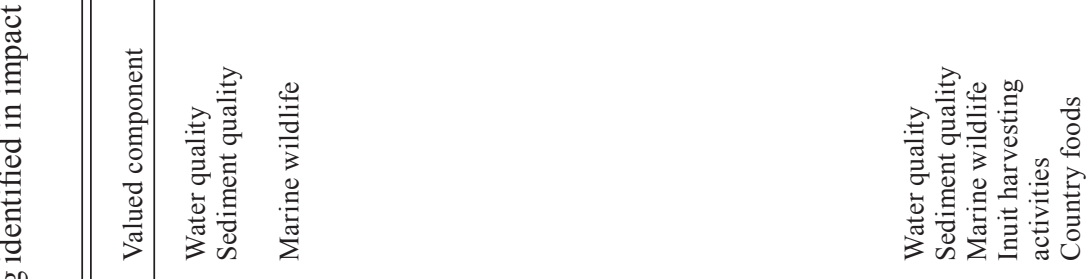

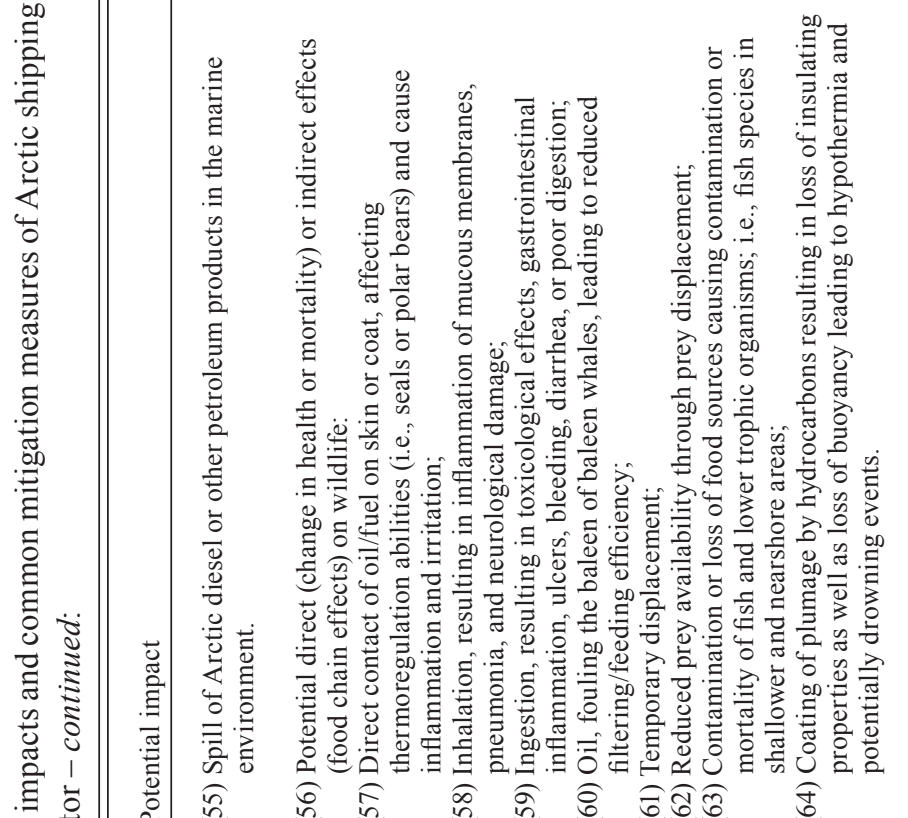

灵

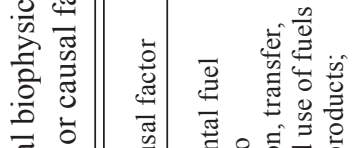

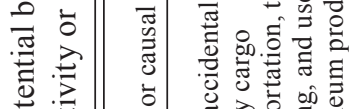

今.

i

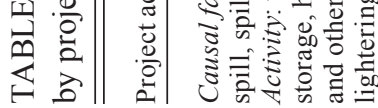

굴

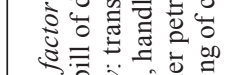

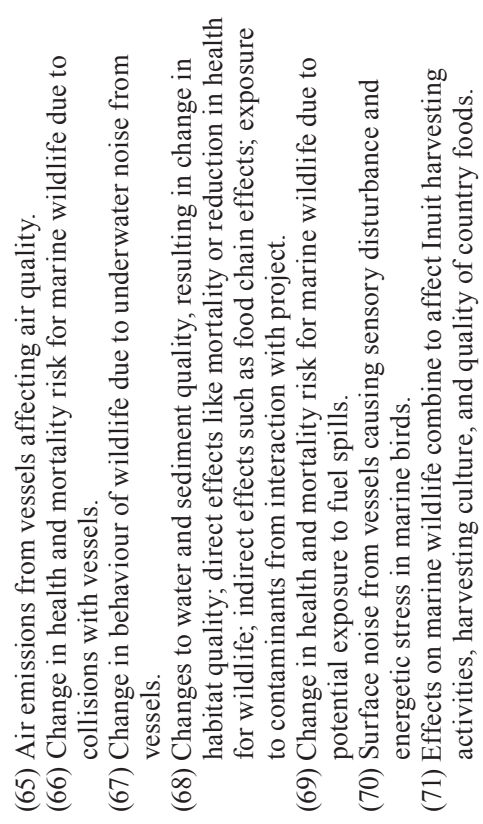


foraging; cultural resources such as archeological sites; travel and mobility; and traditional and current landuse. One routine impact across the sample of IAs was the combination of effects to water and sediment quality, marine birds, fish, and mammals and the subsequent adverse impacts to Inuit harvesting activities and harvesting culture. Such impacts were sometimes termed "in-project cumulative effects" in the EISs-biophysical effects that combine to ultimately affect harvesting practices. Mitigation measures for these cumulative effects restated the mitigation measures for each respective $\mathrm{VC}$ and did not offer any additional measures specific to the affected human components. The second common impact was the disturbance or removal of archeological sites in the project's footprint. Mitigation measures focused on avoidance measures and minimization, ensuring predevelopment surveys and adhering to protocols under archeological permits issued by the Government of Nunavut for systematic data recovery if previously unknown sites are discovered during development.

\section{Impact Management on the Mitigation Hierarchy}

Mitigation translates the findings of the IA into recommendations on a hierarchy of avoid, minimize, or compensate for project impacts - the first two actions are options for ameliorating impacts, whereas compensating refers to making up for or creating new values (Larsen et al., 2018). Mitigation measures along the hierarchy can also be compliance-based, which requires project proponents or activities to operate in accordance with applicable legislation and regulations. According to an NIRB staff member, the assumption is that by complying with stated legislation or regulations, impacts are either avoided or sufficiently small enough to be deemed acceptable. Results show that shipping operations in the NSA rely largely on compliance-based measures (Table 2). Avoidance measures are typically adopted through project design, while minimizing measures use best management practices to minimize risk and meet regulatory compliance. Compensation measures were the least common and are often part of Inuit Impact Benefit Agreements (IBA), which are established separate to the IA process and not part of the public IA record.

Compliance-based: Proponents, like operators in southern Canada, are subject to legislation and regulations at the territorial or provincial, federal, and international level. Federally, the Canada Shipping Act (2001) is the most extensive, with 59 regulations under the Act covering areas like anchorage, ballast water control and management, navigation safety, and hull construction. Proponents are also subject to the Fisheries Act (1985), the Migratory Birds Convention Act (1994), and the Species at Risk Act (2002), among others. Federal and international laws outline the requirements for vessels transporting fuel, including equipment, training, and procedures. However, many of these regulations are not specific to the Arctic environment.
The Arctic Waters Pollution Prevention Act (1985) provides two regulations that aim to prevent pollution in Canadian Arctic waters. The Act is effectively a 'zero discharge' act, which states, "no person or ship shall deposit or permit the deposit of waste of any type in the Arctic waters" (section 4(1)).

Avoidance: Impact avoidance is most effective when considered early in the IA process, and project design elements are still flexible. Of the avoidance measures identified in IA documents, most involved project design strategies such as locating in-water infrastructure away from fish-bearing water or known habitat sites or timing construction events outside of spawning seasons (see Table 2). Interestingly, the Back River and Hope Bay IAs (projects that involved open-water shipping only) presented the shipping season as an avoidance measure for impacts to, for example, the winter habitats of marine mammals. However, NIRB staff indicated that the shipping season often has more to do with community opposition to yearround shipping.

Minimization: Measures to minimize impacts were primarily found in a project's shipping management plan (SMP) and presented as best management practices in addition to regulatory compliance (see Table 2). An SMP covers many operation details ranging from lightering procedures (loading or unloading ships), spill prevention and response, waste management, wildlife protocols, and communication equipment. Best practices in SMPs are often presented as management measures for multiple impacts; for example, measures to minimize adverse effects on water and sediment quality, such as managing runoff, are often cited as measures to minimize adverse food chain effects for marine fish.

SMPs varied in the extent to which minimization measures were precise and thus likely to be verifiable through monitoring. Construction of in-water infrastructure was one example where measures were observed to be precise and present specific practices, such as the use of bubble or silt curtains during blasting events and following Department of Fisheries and Oceans Canada's (DFO) guidelines for overpressure thresholds to protect fish, or applying specific windows for activities outside of sensitive periods for mammals, birds, or fish. Setbacks (i.e., maintaining a distance) from sensitive habitat sites such as migratory bird sanctuaries or walrus uglit (haulouts) along a shipping route were also identified and can be verified through monitoring.

However, other measures were less precise. One combination of mitigation measures that was routinely applied was "reducing speed" and "maintaining a constant speed and course" (see Table 2). For example, slowing vessels down was used to minimize the effects of activities such as icebreaking on landfast ice; to lessen anthropogenic noise disturbance effects to marine mammals; or to reduce the risk of mammal ship strikes. However, the NIRB and intervenors in IA processes raised concerns over uncertainty in the effectiveness of such measures 
and whether implementation could be verified. For example, gaps in acoustic data for Arctic species in noise models, such as for ringed seals, as well as limited data on the effectiveness of reducing ship speed made impact predictions and significance determinations uncertain with respect to the effects of underwater noise in Arctic environments (NIRB, 2012:154).

Compensation: Only one compensation measure was identified as routine: the creation of new fish habitat through fisheries authorizations in the event of the harmful alteration, disruption, or destruction of fish habitat under the Fisheries Act (see Table 2). Compensation was also used for impacts affecting Inuit harvesting activities and mobility, but the details of compensation were rarely reported. Some projects indicated that the specifics of compensation would be established through an Inuit IBA, which are not part of the public IA record (e.g., as discussed in NIRB, 2014b, 2017, 2018a).

\section{Impact Management after Approval}

Following project approval, the NIRB plays a unique role in monitoring. The NIRB focus group described the NIRB's monitoring officers as "the eyes of the communities." Project certificates authorize a project to proceed and contain specific terms and conditions that must be implemented, including mitigation measures. The NIRB engages in effects monitoring (measuring and interpreting changes to environmental and socioeconomic parameters to identify effects and test impact predictions) and compliance monitoring (determining if the land or resources use in question meets regulatory compliance) (NIRB, 2018d). Proponents are required to submit annual reports to the NIRB; larger projects such as mines have additional requirements, including a project monitoring officer, site visits, and community updates.

Regulators like DFO or Environment Canada, submit a compliance-monitoring report to the NIRB, showing the project's compliance with their respective permits and authorizations (Barry et al., 2016). While the ultimate responsibility for monitoring lies with the proponent, the NIRB coordinates project monitoring and reporting and sets the specifics of the programs, rather than duplicate efforts among the proponent and regulators. While these types of monitoring are not unique to Nunavut, the NIRB is empowered through Article 12.7 of the Nunavut Agreement (1993) to amend project certificate conditions including reconsideration of mitigation or monitoring in response to unanticipated project effects, unexpected monitoring results, or management actions that are not as effective as anticipated. This monitoring function is intended to create an adaptive management cycle, identified as essential for managing uncertainty in Arctic operations.

During the staff focus group, reference was made about requiring shipboard observers (SBO) in certificate conditions as an example of adaptive management. The certificate for Mary River requires the use of SBO to monitor for marine mammals and birds along the shipping route and provide notification of any ship strikes (NIRB, 2014a). The proponent discontinued the SBO program in 2016 because of safety concerns over transferring observers from smaller vessels to vessels at sea. Another reason given was the limited number of mammals observed (NIRB, 2018c). In the 2017 - 18 monitoring report from the NIRB, the proponent was found to be non-compliant with these conditions. The NIRB's subsequent recommendation was that the proponent develop alternate strategies for monitoring vessel interactions with marine mammals should the SBO program continue to be unsafe (NIRB, 2018c). In the 2018 monitoring report submitted by the proponent, the initial safety concerns were mitigated using dedicated survey platform and onboard accommodation for Inuit observers on an ice management vessel. This solution, which allowed for consecutive days or weeks of wildlife surveys instead of occasional onboarding at sea, proved itself through a substantial increase in wildlife sightings. In 2018, 551 sightings totaling 2766 individual mammals were observed compared to 65 mammals in 2013, 12 in 2014, and 16 in 2015, although no ship strikes were reported over the four years (NIRB, 2019a).

\section{Challenges to Managing Impacts}

Key challenges identified from the document review and highlighted by the focus groups on managing the impacts of Arctic shipping through IA include uncertainty, assessing the appropriateness of existing mechanisms (e.g., laws, regulations, best practices) to manage shipping in Arctic environments, and addressing the cumulative effects of increasing development. Focus groups reported that reliance on compliance-based measures and best management practices introduces challenges over enforcement, communication, and capacity in a vast and remote region. Some federal regulators who administer key legislation and regulations, many of which have their own enforcement provisions, operate from southern Canada and do not have a permanent presence in the Arctic, which leads to obvious practical challenges in enforcement (e.g., managing complaints over non-compliance from community members). Focus group participants raised this as an issue for engaging with communities after an IA is completed, noting: "they [federal regulators] aren't aware of the Arctic and the Arctic isn't aware of them." Focus group participants noted that the NIRB has had to reinforce the responsibilities of federal regulators through project certificate terms and conditions to help ensure that regulators meaningfully participate in compliance monitoring and enforcement.

A focus on compliance also raised questions over the effectiveness of these measures for sensitive Arctic environments. Focus group participants reported that in making decisions on project approvals, the NIRB must ask whether compliance-based measures, which were largely developed to regulate shipping outside of the Arctic 
(e.g., Ballast Water Control and Management Regulations), are precautious enough for Arctic waters.

This task is made harder by uncertainty or gaps in scientific data or when regulators are not fully resourced to effectively participate in the process; participants gave the example of not providing a qualified subject matter expert at technical meetings or public hearings, which made the board's decision-making that much harder. Participants reported that gaps in baseline data present practical challenges in assessing impact predictions, significance determinations, and mitigation. For example, in the Hope Bay public hearing, the NIRB noted that data deficiencies (not specific to the project) limited the ability of regulators to have confidence in the assessment of cumulative effects. In the final public hearing, a representative from DFO noted that, "taken as a whole, we don't know what the threshold is... We're pretty data deficient right now when it comes to the cumulative impacts of shipping on marine mammals in the North" (NIRB, 2018a:287). A similar data issue over ballast water exchange and management in the Mary River public hearing was reported in the focus group, especially over the cumulative effects of exchange over the project's 30 -year lifespan. In the NIRB's view, while monitoring can allow for responsive adaptive management, regulatory authorities might also be more proactive and diligent with regulatory inspections, oversight and enforcement than might be routine for other areas, given the unprecedented nature of Mary River in the NSA (NIRB, 2012). However, regulatory capacity is limited for agencies with only seasonal or no presence in Nunavut.

Concern was also highlighted by focus group participants over the regulatory capacity and gaps in other permitting processes for activities that do not trigger an IA screening. For example, tourism is seen by the NIRB and communities as a "really big issue because of waste dumping, amount of foot traffic in marine marginal areas, and now scuba diving, snorkelling, [and] chumming for Greenland sharks." From the NIRB's perspective, regulators like Parks Canada are seeing this change in the number of large cruise ships that unexpectedly might decide to stop near a national park, but Parks Canada does not have the capacity to effectively supervise a visit or regulate activity. The NIRB indicates that it is "keenly aware" of concerns about the cumulative effects of increasing traffic, and this concern is routinely raised by community members in public hearings. The NIRB generally accepts that the potential for cumulative effects from projects can be effectively managed by implementing the mitigation, monitoring and adaptive management measures proposed by proponents (NIRB, 2018a:282). Given the confines of project-based IA, focus group participants indicated that IAs do not provide the appropriate venue for addressing these more general concerns about future development and data deficiencies.

The focus on compliance-based mitigation coupled with questions over the cumulative effects of ship traffic was highlighted in the focus group, with reference to a question raised in the Hope Bay IA. The proponent argued over the necessity of requiring an SMP given the focus on regulatory compliance, further prompting questions about how the potential cumulative effects of shipping on marine mammals should be dealt with. It was the NIRB's view that it would be "most appropriate for the Government of Canada to establish and implement standardized requirements that would pertain to all certified vessels transiting through Arctic waters, rather than placing the onus on proponents" (NIRB, 2018a:282).

This discussion arose during the focus group around the application of a similar program mentioned earlier: shipboard observers. Participants recounted that a federal regulator wanted to implement SBOs for Hope Bay vessels because of their prediction of whale strikes and concern for cumulative effects in the study area. There were two problems that arose in the public hearings. First, there was contention over the underlying assumptions of the regulator's model. Their model for whale strikes predicted an unusually high number of strikes (around 20 per year) from one project alone. However, it was discovered that the model assumed that whales did not move when a ship approaches. As one NIRB member recalled during the focus group: "It would be a lot easier to hunt if they didn't move!" The regulator was using this model because of a lack of data on an Arctic species. This lack of data was not only the case in Hope Bay, but in all IAs. Focus group participants indicated that federal regulators encourage adaptive management approaches to meet their own data needs, and the onus is put on proponents to fill data gaps on species under their jurisdiction. The challenge for the NIRB and for proponents is avoiding regulators' front-loading the IA process with their own needs. As one participant explained, the NIRB is put in the position of "finding a balance between creating opportunities through monitoring programs to fill data gaps and having to accept and deal with high levels of uncertainty."

The second issue in the SBO case was that the sealift activities associated with Hope Bay are not functionally different from the community sealift, often using the same contractors. Focus group participants explained that the NIRB took the position that the responsibility for such measures does not lie with one proponent and their shipping contractor but with the industry that the federal government regulates. In the NIRB's view, SBOs can be appropriate for projects like Mary River, where the proponent has direct control over vessels. There is a need for a more strategic approach to regulate Arctic shipping; requiring SBOs for individual project proponents does little to monitor or mitigate the effects of other types of important marine traffic, like tourism or community resupply.

\section{DISCUSSION}

The first priority of the mitigation hierarchy in IA is to avoid impacts, the second is to minimize impacts, and the last resort is to compensate for any impacts-a 
mitigation hierarchy "upside down" can illustrate a failure in implementation (Larsen et al., 2018). The management approach taken in IA for mine-based shipping in Nunavut is best described as minimize, avoid, and compensate (see Table 2). Avoidance measures tended to be temporal or spatial, involving either the timing of events or setbacks from known habitat areas. The IA document review revealed that unlike other jurisdictions (Tinker et al., 2005; Larsen et al., 2018), proponents explicitly highlighted where design decisions have been made to avoid impacts. This requirement is set in an IAs terms of reference; the NIRB requires proponents to demonstrate how public consultation and IQ influenced planning and design of the project (NIRB, 2018b).

Measures to minimize impacts were applied in both construction and operation phases through best practices that are used to manage the impacts of marine development in other environments, such as the use of bubble or silt curtains in construction (Jacob et al., 2016). Compliancebased measures could be categorized as either avoid or minimize depending on their intent: for example, the required use of conventional double-hulled petroleum tankers under MARPOL could be considered a measure to avoid a catastrophic oil spill, but ultimately minimizes the risk of an accident. Lastly, compensation was not a routine mitigation strategy. Where compensation was used, it was often to address social or cultural impacts to Inuit harvesting activities and land-use through IBAs. IBAs are common in the Canadian Arctic and are an increasingly common business practice in the mining sector (Noble and Hanna, 2015). Jacob et al. (2016) observed in their study on the mitigation hierarchy in IAs for marine and coastal development projects that compensation is more readily applied to socioeconomic impacts, since the significance threshold is considered lower than for biophysical impacts.

Focus group results suggest that an important and sometimes technically difficult task in the Arctic is assessing whether shipping legislation, regulation or best practices designed elsewhere are precautious enough for Arctic environments and the realities of polar operations. Gaps in scientific baseline data on Arctic species, where southern species are used in modelling, often lead to uncertainty in impact predictions, which is further compounded by rapidly changing Arctic environment baselines (Arctic Council, 2016).

The NIRB's comprehensive monitoring function is thus an important part of a precautionary approach to managing shipping impacts whereby the NIRB, regulators, and the proponent collaborate to monitor project effects and regulatory compliance, and to test impact predictions and the effectiveness of mitigation. Importantly, the NIRB is enabled through legislation to adjust terms and conditions to reflect monitoring results-a provision that is essential to creating an adaptive management strategy (MorrisonSaunders et al., 2003; Tinker et al., 2005) and creating the capacity to cope with, prepare for, and adapt to uncertain or changing social-ecological conditions (Dale and
Armitage, 2011). Results from such monitoring activities can also contribute to an important learning outcome for IA; how to design and manage projects that mitigate adverse effects and enhance benefits (Cashmore et al., 2004; Chanchitpricha and Bond, 2013). If subsequent IAs can build on prior investigations, over time it becomes possible to significantly improve the understanding of the impacts and ecosystemic factors (Greig and Duinker, 2011). This improvement is especially the case as the Mary River project develops and generates new monitoring data on such issues as the distribution of ringed seals and implications for icebreaking (Yurkowski et al., 2019) or on the risk of invasive species in ballast water exchange in Davis Strait (Goldsmit et al., 2019). Understanding impact outcomes and mitigation effectiveness for these "routine" measures can not only inform management for the Mary River project but can inform best practices for shipping impact mitigation in the NSA.

However, there are some key challenges. First, the effectiveness of compliance-based measures assumes the regulatory capacity for enforcement; having rules is one thing, their implementation and the means to enforce compliance is another (Guy and Lasserre, 2016). For many impacted communities in Nunavut, enforcement is a major concern given the remoteness of the region, the limits of the Canadian Coast Guard and other emergency response, and the lack of physical presence of regulators like Transport Canada or DFO (Thiessen, 2019). The lack of clarity around roles and responsibilities for ensuring the implementation of mitigation measures is a challenge because it can "increase the risk of inexpedient or no implementation" (Larsen et al., 2018:293). To get ahead of this challenge, the NIRB includes explicit references to the responsibilities of regulators in project terms and conditions. Despite these requirements, the NIRB expressed caution in the public hearings for the Mary River, Meliadine, Back River, and Hope Bay projects over the regulatory capacity of authorizing agencies to meaningfully participate in follow-up activities (NIRB, 2012, 2014b, 2017, 2018a).

Second, results from this research indicate concerns over the ability of the current IA system to effectively manage the cumulative effects of increasing Arctic traffic. In the case of the Hope Bay project SBO, for example, a regulatory gap was noted by the NIRB: many of the contributors to the substantial increase in marine traffic (i.e., community resupply and cruise ships) are not captured by the NIRB's project-specific assessments and therefore an individual IA is not the venue for "determining whether additional regulations may be required for shipping in the Canadian Arctic" (NIRB, 2018a:287). This gap is acknowledged by communities in Nunavut, especially those close to shipping routes (Thiessen, 2019). The challenges of assessing cumulative effects through project-based IAs are well documented in recent scholarship (Duinker et al., 2013; Noble et al., 2017; Sinclair et al., 2017) and are not unique to the Canadian Arctic (Cherp and Golubeva, 2004). Foley et al. (2017), for example, report that, despite scientific 
advances and regulatory efforts to address the effects of multiple, overlapping stressors on ocean and coastal environments, practitioners, proponents, and regulators continue to struggle to address cumulative effects as part of IA processes. Identifying cumulative effects can be a technically challenging process and likely even beyond the capacity of project-focused IA (Wong et al., 2019), even though cumulative effects may seem obvious to communities directly observing change over time (Arnold et al., 2019). Results suggest that notwithstanding a meaningful IA process for shipping, including mitigation strategies and follow-up programs, an increasing number of shipping activities in the Arctic are not subject to such assessment and mitigation planning.

Third, and closely related to the above, given that only a minority projects undergo an IA, managing the impacts of Arctic shipping requires a more strategic approach. There is a tendency for issues to emerge during IAs that are beyond the scope of what can be addressed in project-based IA, a challenge that is not unique to the Arctic (Udofia et al., 2015). Results from this research show that the NIRB's process becomes a repository for regional concerns about the cumulative contribution of shipping not captured through IA, and that an individual IA is not the venue to address these regional concerns, as illustrated by the Hope Bay assessment. For many Indigenous communities across Canada, however, including the Arctic, the IA process is often the only opportunity in the regulatory process to raise concerns about development impacts. Since most projects and activities do not trigger an IA, few opportunities exist to engage in meaningful discussions about development impacts and regional concerns (Udofia et al., 2017). Regional or strategic assessments can provide better opportunities to address concerns over the appropriateness of different types of development within a region, help communities define the most desirable growth scenarios, and capture those shipping activities that individually and cumulatively affect Arctic environments and communities, but do not necessarily trigger an IA (CCME, 2009; Fidler and Noble, 2013; Noble and Hanna, 2015). There have been some promising developments in the eastern Arctic, including the recent strategic assessment of offshore oil and gas development (NIRB, 2019b); the cumulative effects assessment of shipping across Canada as part of the Oceans Protection Plan (GC, 2018; Lerner, 2018), and the development under the same federal initiative of lowimpact Arctic shipping corridors (see Porta et al., 2017).

Nunavut's land-use planning process, which also refers to the marine environment under the Nunavut Agreement, provides a more strategic approach for generating baseline data, defining management objectives, and easing the consultation burden placed on communities (Fidler and Noble, 2013). Currently, however, only one and a half out of three regions in Nunavut are covered under a plan, both of which have not been substantially updated since their approval in 2000 (NPC, 2016). When land-use plans are not kept current and consistent with residents' values, the
IA process can be inundated with regional issues during a screening or IA for a single project (Barry et al., 2016; NPC, 2016). A draft Nunavut Land Use Plan was released in 2016 but consultation processes have been stalled since early 2017 (NPC, 2016). Nonetheless, the experience and knowledge gained through IA can contribute to managing other types of shipping in the region.

\section{CONCLUSIONS}

This paper identified the routine impacts of Arctic shipping considered in IA practice and the management approaches adopted in project design, mitigation, and follow-up. Results from a review of recent IAs in the NSA identified 71 impacts to the biophysical environment and two impacts to the human environment that were common across the sample of IA documents. The approach to managing these impacts is based on a combination of measures applied to minimize and avoid impacts based on legislation, regulation, and best management practices. However, there are enduring concerns over the regulatory capacity of authorizing agencies to monitor and enforce compliance-based mitigation strategies. The challenges are exacerbated when mitigation relies heavily on standards developed external to Arctic environments, coupled with an assumption that mitigation is implemented and effective.

IA is an integral tool for managing the impacts of Arctic shipping. However, the results also indicate that the IAs are often contending with bigger questions about the increase in shipping traffic in the NSA. Private pleasure boats (noncommercial tourism), for example, were the fastest growing vessel type in the region over the last 25 years and with discoveries such as the Franklin Expedition ships and the allure of last-chance tourism, the demand for Arctic marine tourism will likely grow (Johnston et al., 2017). Regional demographics and a focus on further developing a fisheries economy in Nunavut suggest that general cargo, tug and barge, and fishing traffic may also increase (Dawson et al., 2017). A major challenge is that many of the concerns about the cumulative effects of shipping traffic are poorly addressed by placing the onus solely on an individual project proponent as part of the IA process. Different categories of shipping may require different management approaches depending on operations and scale, but the information generated about shipping impacts and management approaches from IAs can be valuable in refining or developing management approaches and regulatory mechanisms for Arctic shipping at the territorial and federal level.

Given the limits of baseline data in the Arctic, it is unlikely that uncertainties will be substantially reduced over a single IA, but, over time, transferable lessons can be applied based on IA practice. By understanding routine impacts and how they are managed, and the impacts that are not captured under the IA process, there is an opportunity to learn from one project to the next and refine what 'best' 
management practice means for Arctic shipping. Until more regional and sector-wide approaches emerge, an improved sharing of knowledge about routine impacts and known mitigation solutions is essential. Through complementary licensing or permitting processes, this knowledge can then be applied to shipping activities that are not subject to a IA, but share many of the same operational details and thus likely impacts.

\section{ACKNOWLEDGEMENTS}

This research was supported by funding from Irving Shipbuilding Inc, the Nunavut Research Institute, the Northern Scientific Training Program, and Polar Knowledge Canada. We also wish to acknowledge the important support of the Nunavut Impact Review Board. The time and constructive comments of peer reviewers is greatly appreciated.

\section{REFERENCES}

Arctic Council. 2016. Arctic resilience report. Edited by Carson, M., and Peterson, G. Stockholm: Stockholm Environment Institute and Stockholm Resilience Centre. https://oaarchive.arctic-council.org/handle/11374/1838

Arctic Waters Pollution Prevention Act. 1985. R.S.C., 1985. c. A-12. https://laws-lois.justice.gc.ca/eng/acts/A-12/

Arnold, L.M., Hanna, K., and Noble, B. 2019. Freshwater cumulative effects and environmental assessment in the Mackenzie Valley, Northwest Territories: Challenges and decision-maker needs. Impact Assessment and Project Appraisal 37(6):516 - 525. https://doi.org/10.1080/14615517.2019.1596596

Barry, R., Granchinho, S.C.R., and Rusk, J. 2016. Impact assessment in Nunavut. In: Hanna, K.S., ed. Environmental impact assessment: Practice and participation, $3^{\text {rd }}$ ed. Don Mills, Ontario: Oxford University Press. $267-298$.

Brooks, M.R., and Frost, J.D. 2012. Providing freight services to remote Arctic communities: Are there lessons for practitioners from services to Greenland and Canada's northeast? Research in Transportation Business \& Management 4:69 - 78.

https://doi.org/10.1016/j.rtbm.2012.06.005

Canada and Tunngavik Federation of Nunavut. 1993. Nunavut Land Claims Agreement Act: An Act respecting an agreement between the Inuit of the Nunavut Settlement Area and Her Majesty the Queen in right of Canada. S.C. 1993, c. 29. Ottawa: Minister of Justice.

https://laws-lois.justice.gc.ca/eng/acts/n-28.7/FullText.html

Canada Shipping Act. 2001. S.C. 2001 c. 26. https://laws-lois.justice.gc.ca/eng/acts/c-10.15/

Cashmore, M., Gwilliam, R., Morgan, R., Cobb, D., and Bond, A. 2004. The interminable issue of effectiveness: Substantive purposes, outcomes and research challenges in the advancement of environmental impact assessment theory. Impact Assessment and Project Appraisal 22(4):295 - 310. https://doi.org/10.3152/147154604781765860
CCME (Canadian Council of Ministers of the Environment). 2009. Regional strategic environmental assessment in Canada: Principles and guidance. Winnipeg, Manitoba: CCME.

https://www.ccme.ca/files/Resources/enviro_assessment/ rsea_principles_guidance_e.pdf

Chanchitpricha, C., and Bond, A. 2013. Conceptualising the effectiveness of impact assessment processes. Environmental Impact Assessment Review 43:65 - 72.

https://doi.org/10.1016/j.eiar.2013.05.006

Cherp, A., and Golubeva, S. 2004. Environmental assessment in the Russian Federation: Evolution through capacity building. Impact Assessment and Project Appraisal 22(2):121 - 130. https://doi.org/10.3152/147154604781766030

Chircop, A. 2009. The growth of international shipping in the Arctic: Is a regulatory review timely? International Journal of Marine and Coastal Law 24(2):355 - 380.

https://oi.org/10.1163/157180809X421699

CCA (Council of Canadian Academies). 2016. Commercial Marine Shipping Accidents: Understanding the Risks in Canada. Workshop Report. Ottawa, Ontario: CCA.

https://cca-reports.ca/reports/commercial-marine-shippingaccidents-understanding-the-risks-in-canada/

- 2017. The value of commercial marine shipping to Canada. Expert Panel on the Social and Economic Value of Marine Shipping to Canada. Ottawa, Ontario: CCA.

CCME (Canadian Council of Ministers of the Environment). 2014a. Dioxins and furans. https://www.ccme.ca/en/resources/air/dioxins_furans.html - 2014b. Mercury. https://www.ccme.ca/en/resources/air/mercury.html

Dale, A., and Armitage, D. 2011. Marine mammal co-management in Canada's Arctic: Knowledge co-production for learning and adaptive capacity. Marine Policy 35(4):440 - 449.

https://doi.org/10.1016/j.marpol.2010.10.019

Dawson, J., Mussells, O., Copland, L., and Carter, N. 2017. Shipping trends in Nunavut 1990 - 2015: A report prepared for the Nunavut General Monitoring Program. Ottawa, Ontario: Dept. of Geography, Environment and Geomatics, University of Ottawa.

http://www.espg.ca/wp-content/uploads/2013/04/NGMPShipping-Report_2017-V1.pdf

Dawson, J., Pizzolato, L., Howell, S.E.L., Copland, L., and Johnston, M.E. 2018. Temporal and spatial patterns of ship traffic in the Canadian Arctic from 1990 to 2015. Arctic 71(1):15-26. https://doi.org/10.14430/arctic4698

DFO (Department of Fisheries and Oceans Canada). 2019. Measures to protect fish and fish habitat. Ottawa, Ontario: DFO.

https://www.dfo-mpo.gc.ca/pnw-ppe/measures-mesures-eng. html

Duinker, P.N., Burbidge, E.L., Boardley, S.R., and Greig, L.A. 2013. Scientific dimensions of cumulative effects assessment: Toward improvements in guidance for practice. Environmental Reviews 21(1):40 - 52 .

https://doi.org/10.1139/er-2012-0035 
Egede Dahl, P.P., and Hansen, A.M. 2019. Does Indigenous knowledge occur in and influence impact assessment reports? Exploring consultation remarks in three cases of mining projects in Greenland. Arctic Review on Law and Politics 10:165 - 189 .

https://doi.org/10.23865/arctic.v10.1344

Fidler, C., and Noble, B.F. 2013. Stakeholder perceptions of current planning, assessment and science initiatives in Canada's Beaufort Sea. Arctic 66(2):179 - 190.

https://doi.org/10.14430/arctic4289

Fisheries Act. 1985. R.S.C., 1985, c. F-14. https://laws-lois.justice.gc.ca/eng/acts/f-14/

Foley, M M., Mease, L.A., Martone, R.G., Prahler, E.E., Morrison, T.H., Murray, C.C., and Wojcik, D. 2017. The challenges and opportunities in cumulative effects assessment. Environmental Impact Assessment Review 62:122 - 134.

https://doi.org/10.1016/j.eiar.2016.06.008

GC (Government of Canada). 2018. Cumulative effects of marine shipping. Ottawa.

https:/letstalktransportation.ca/cumulative-effects

GN (Government of Nunavut). 2002. Environmental guideline for dust suppression. Iqaluit: Department of Sustainable Development, Environmental Protection Service.

https:/gov.nu.ca/sites/default/files/Guideline\%20Dust $\% 20$ Suppression.pdf

. 2012. Guideline for burning and incineration of solid waste. Iqaluit: Department of Environment.

https://www.gov.nu.ca/environment/documents/guidelineburning-and-incineration-solid-waste-2012

- n.d. Inuit Qaujimajatuqangit. Iqaluit: Government of Nunavut.

https://www.gov.nu.ca/sites/default/files/iq_brochure_draft_1. pdf

Goldsmit, J., Nudds, S.H., Stewart, D.B., Higdon, J.W., Hannah, C.G., and Howland, K.L. 2019. Where else? Assessing zones of alternate ballast water exchange in the Canadian eastern Arctic. Marine Pollution Bulletin 139:74 - 90. https://doi.org/10.1016/j.marpolbul.2018.11.062

Gondor, D. 2016. Inuit knowledge and environmental assessment in Nunavut, Canada. Sustainability Science 11(1):153 - 162. https://doi.org/10.1007/s11625-015-0310-z

Greig, L.A., and Duinker, P.N. 2011. A proposal for further strengthening science in environmental impact assessment in Canada. Impact Assessment and Project Appraisal 29(2):159- 165 . https://doi.org/10.3152/146155111X12913679730557

Guy, E., and Lasserre, F. 2016. Commercial shipping in the Arctic: New perspectives, challenges and regulations. Polar Record 52(3):294 - 304. https://doi.org/10.1017/S0032247415001011

Jacob, C., Pioch, S., and Thorin, S. 2016. The effectiveness of the mitigation hierarchy in environmental impact studies on marine ecosystems: A case study in France. Environmental Impact Assessment Review 60:83 - 98. https://doi.org/10.1016/j.eiar.2016.04.001
Johnston, M., Dawson, J., De Souza, E., and Stewart, E.J. 2017. Management challenges for the fastest growing marine shipping sector in Arctic Canada: Pleasure crafts. Polar Record 53(1):67 - 78 . https://doi.org/10.1017/S0032247416000565

Karetak, J., and Tester, F. 2017. Introduction: Inuit Qaujimajatuqangit. In: Karetak, J., Tester, F., and Tagalik, S., eds. Inuit Qaujimajatuqangit: What Inuit have always known to be true. Halifax, Nova Scotia: Fernwood Publishing. 1 - 19.

Koivurova, T. 2008. Transboundary environmental assessment in the Arctic. Impact Assessment and Project Appraisal 26(4):265 - 275 . https://doi.org/10.3152/146155108X366031

Larsen, J.N., Anisimov, O.A., Constable, A., Hollowed, A.B., Maynard, N., Presturd, P., Prowse, T.D., and Stone, J.M.R. 2014. Polar regions. In: Barros, V.R., Field, C.B., Dokken, D.J., Mastrandrea, M.D., Mach, K.J., Bilir, T.E., Chatterjee, M., et al., eds. Climate change 2014: Impacts, adaptation, and vulnerability. Part B: Regional aspects. Contribution of Working Group II to the Fifth Assessment Report of the Intergovernmental Panel on Climate Change. Cambridge: Cambridge University Press. 1567 - 1612.

Larsen, S.V., Kørnøv, L., and Christensen, P. 2018. The mitigation hierarchy upside down - a study of nature protection measures in Danish infrastructure projects. Impact Assessment and Project Appraisal 36(4):287 - 293. https://doi.org/10.1080/14615517.2018.1443260

Lasserre, F., and Têtu, P.-L. 2015. The cruise tourism industry in the Canadian Arctic: Analysis of activities and perceptions of cruise ship operators. Polar Record 51(1):24 - 38. https://doi.org/10.1017/S0032247413000508

Lerner, J. 2018. Review of cumulative effects management concepts and international frameworks. Prepared for Transport Canada. Vancouver, British Columbia: UBC Institute for Resources, Environment, and Sustainability.

https://ww w.tc.gc.ca/eng/review-cumulative-effectsmanagement-concepts-international-frameworks.html

Lévesque, F. 2015. Revisiting Inuit Qaujimajatuqangit: Inuit knowledge, culture, language, and values in Nunavut institutions since 1999. Études/Inuit/Studies 38(1-2):115 - 136. https://doi.org/10.7202/1028856ar

McWhinnie, L.H., Halliday, W.D., Insley, S.J., Hilliard, C., and Canessa, R.R. 2018. Vessel traffic in the Canadian Arctic: Management solutions for minimizing impacts on whales in a changing northern region. Ocean \& Coastal Management 160:1 - 17 . https://doi.org/10.1016/j.ocecoaman.2018.03.042

Migratory Birds Convention Act. 1994. S.C. 1994, c. 22. https://laws-lois.justice.gc.ca/eng/acts/m-7.01/

Minister of Justice. 2010. Northern Canada vessel traffic services zone regulations. Ottawa: Government of Canada. https://laws-lois.justice.gc.ca/eng/Regulations/SOR-2010-127/ index.html

Morgan, R.K. 2012. Environmental impact assessment: The state of the art. Impact Assessment and Project Appraisal 30(1):5 - 14 .

https://doi.org/10.1080/14615517.2012.661557 
Morrison-Saunders, A., Baker, J., and Arts, J. 2003. Lessons from practice: Towards successful follow-up. Impact Assessment and Project Appraisal 21(1):43 - 56.

https://doi.org/10.3152/147154603781766527

NIRB (Nunavut Impact Review Board). 2012. Final hearing report: Mary River Project, Baffinland Iron Mines Corporation. NIRB File No. 08MN053. File name: 120914-08MN053-NIRB Final Hearing Report-OEDE.pdf. Cambridge Bay, Nunavut: NIRB. https://www.nirb.ca/project/123910

- 2014a. Mary River project certificate no. 005. File name: 140528-08MN053-NIRB Project Certificate No 005 Amendment 1-ODTE.pdf. Cambridge Bay, Nunavut: NIRB. https://www.nirb.ca/project/123910

— 2014b. Final hearing report: Meliadine Gold Project, Agnico Eagle Mines Limited. NIRB File No. 11MNO34. File name: 141010-11MN034-NIRB Final Hearing Rpt-OEDE.pdf. Cambridge Bay, Nunavut: NIRB.

https://www.nirb.ca/portal/pdash.php?appid=124106

— 2017. Revised final hearing report: Back River Gold Mine Project, Sabina Gold and Silver Corp. NIRB File No. 12MN036. File name: 170718-12MN036-Revised Final Hearing ReportOT8E.pdf. Cambridge Bay, Nunavut: NIRB.

https://www.nirb.ca/project/124149

- 2018a. Final hearing report: Phase 2 Hope Bay Belt Project, TMAC Resources Inc. NIRB File No. 12MN001. File name: 180626-12MN001-Final Hearing Report-OT1E.pdf. Cambridge Bay, Nunavut: NIRB.

https://www.nirb.ca/portal/pdash.php?appid=124148

- 2018b. Standard guidelines for the preparation of an impact statement. Cambridge Bay, Nunavut: NIRB.

http://www.nirb.ca/publications/Rules\%20 of \% 20

Procedure/181206-DRAFT\%20NIRB\%20Standard\%20 IS\%20Guidelines_English-OEDE.pdf

—. 2018c. 2017-2018 annual monitoring report for Baffinland Iron Mines Corp.'s Mary River Project. NIRB File No. 08MN053. File name: 181108-08MN053-Monitoring Report-OT5E.pdf. Cambridge Bay, Nunavut: NIRB. https://www.nirb.ca/portal/pdash.php?appid=123910

\section{NIRB.}

http://www.nirb.ca/publications/guides2/181127-NIRB $\% 20$ Proponents'\%20Guide-FINAL.pdf

- 2019a. The Nunavut Impact Review Board's 2018 - 2019 annual monitoring report for Baffinland Iron Mines Corporation's Mary River Project. NIRB File No. 08MN053. Cambridge Bay, Nunavut: NIRB.

https://www.nirb.ca/project/123910

- 2019b. Final report for the strategic environmental assessment in Baffin Bay and Davis Strait. SEA summary report Vol. 1. NIRB File No. 17SN034. File name: 190731-17SN034Final SEA Report-Volume 1-OPAE.pdf. Cambridge Bay, Nunavut: NIRB.

https://www.nirb.ca/portal/pdash.php?appid=125087

Noble, B., and Hanna, K. 2015. Environmental assessment in the Arctic: A gap analysis and research agenda. Arctic 68(3):341-355.

https://doi.org/10.14430/arctic4501
Noble, B., Liu, J., and Hackett, P. 2017. The contribution of project environmental assessment to assessing and managing cumulative effects: Individually and collectively insignificant? Environmental Management 59(4):531 - 545.

https://doi.org/10.1007/s00267-016-0799-7

NPC (Nunavut Planning Commission). 2016 Nunavut land use plan. Iqaluit: NPC.

https:/www.nunavut.ca/land-use-plans/draft-nunavut-landuse-plan

NuPPAA (Nunavut Planning and Project Assessment Act). 2013. S.C. 2013 , c. 14 , s. 2.

http://laws-lois.justice.gc.ca/eng/acts/N-28.75/page-1.html

Olsen, J., Carter, N.A., Dawson, J., and Coetzee, W. 2019. Community perspectives on the environmental impacts of Arctic shipping: Case studies from Russia, Norway and Canada. Cogent Social Sciences 5: 1609189. https://doi.org/10.1080/23311886.2019.1609189

Pizzolato, L., Howell, S.E.L., Derksen, C., Dawson, J., and Copland, L. 2014. Changing sea ice conditions and marine transportation activity in Canadian Arctic waters between 1990 and 2012. Climatic Change 123:161 - 173. https://doi.org/10.1007/s10584-013-1038-3

Porta, L., Abou-Abssi, E., Dawson, J., and Mussells, O. 2017. Shipping corridors as a framework for advancing marine law and policy in the Canadian Arctic. Ocean and Coastal Law Journal 22(1):63 - 84 .

Prowse, T.D., Furgal, C., Chouinard, R., Melling, H., Milburn, D., and Smith, S.L. 2009. Implications of climate change for economic development in northern Canada: Energy, resource, and transportation sectors. AMBIO: A Journal of the Human Environment 38(5):272 - 281.

https://doi.org/10.1579/0044-7447-38.5.272

Public Registry. n.d. Nunavut Impact Review Board. http://www.nirb.ca

Richards, L., and Morse, J.M. 2013. Readme first for a user's guide to qualitative methods, $3^{\text {rd }}$ ed. Thousand Oaks, California: Sage.

Sinclair, A.J., Doelle, M., and Duinker, P.N. 2017. Looking up, down, and sideways: Reconceiving cumulative effects assessment as a mindset. Environmental Impact Assessment Review 62:183 - 194.

https://doi.org/10.1016/j.eiar.2016.04.007

Species at Risk Act. 2002. S.C. 2002, c. 29.

https://laws-lois.justice.gc.ca/eng/acts/s-15.3/

Statistics Canada. 2017. Census profile, 2016 census: Nunavut [Territory] and Canada [Country]. Ottawa, Ontario: Statistics Canada.

https://www12.statcan.gc.ca/census-recensement/2016/dp-pd/ prof/index.cfm?Lang=E

Stephens, H. 2016. The opening of the northern sea routes: The implications for global shipping and for Canada's relations with Asia. SPP Research Paper 9(19) Calgary, Alberta: School of Public Policy, University of Calgary.

https://papers.ssrn.com/sol3/papers.cfm?abstract_id=2808661

Stevenson, M.G. 2006. The possibility of difference: Rethinking co-management. Human Organization 65(2):167 - 180.

https://doi.org/10.17730/humo.65.2.b2dm8thgb7wa4m53 
Stewart, E., Dawson, J., and Johnston, M. 2015. Risks and opportunities associated with change in the cruise tourism sector: Community perspectives from Arctic Canada. The Polar Journal 5(2):403 - 427. https://doi.org/10.1080/2154896X.2015.1082283

Tester, F.J., and Irniq, P. 2009. Inuit Qaujimajatuqangit: Social history, politics and the practice of resistance. Arctic 61(Suppl. 1): $48-61$. https://doi.org/10.14430/arctic101

Têtu, P.-L., Pelletier, J.-F., and Lasserre, F. 2015. The mining industry in Canada north of the 55th parallel: A maritime traffic generator? Polar Geography 38(2):107 - 122. https://doi.org/10.1080/1088937X.2015.1028576

Thiessen, B.M. 2019. Understanding Arctic shipping impacts and mitigation: Impact assessment as a tool for knowledge brokerage. MA thesis, University of Saskatchewan. https://harvest.usask.ca/handle/10388/12221

Tinker, L., Cobb, D., Bond, A., and Cashmore, M. 2005. Impact mitigation in environmental impact assessment: Paper promises or the basis of consent conditions? Impact Assessment and Project Appraisal 23(4):265 - 280. https://doi.org/10.3152/147154605781765463

Udofia, A., Noble, B., and Poelzer, G. 2015. Community engagement in environmental assessment for resource development: Benefits, enduring concerns, opportunities for improvement. The Northern Review 39:98 - 110.

. 2017. Meaningful and efficient? Enduring challenges to Aboriginal participation in environmental assessment. Environmental Impact Assessment Review 65:164 - 174. https://doi.org/10.1016/j.eiar.2016.04.008
Usher, P.J. 2000. Traditional ecological knowledge in environmental assessment and management. Arctic 53(2):183 - 193. https://doi.org/10.14430/arctic849

VanderZwagg, D., Chircop, A., Franckx, E., Kindred, H., MacInnis, K., McConnell, M., McDonald, A., et al. 2008. Governance of Arctic marine shipping. Halifax, Nova Scotia: Marine \& Environmental Law Institute, Dalhousie Law School.

Wenzel, G.W. 2004. From TEK to IQ: Inuit Qaujimajatuqangit and Inuit cultural ecology. Arctic Anthropology 41(2):238 - 250. https://doi.org/10.1353/arc.2011.0067

White, G. 2006. Cultures in collision: Traditional knowledge and Euro-Canadian governance processes in northern land-claim boards. Arctic 59(4):401 - 414.

https://doi.org/10.14430/arctic289

Wong, L., Noble, B., and Hanna, K. 2019. Water quality monitoring to support cumulative effects assessment and decision making in the Mackenzie Valley, Northwest Territories, Canada. Integrated Environmental Assessment and Management 15(6):988 - 999 . https://doi.org/10.1002/ieam.4179

Wright, D.G., and Hopky, G.E. 1998. Guidelines for the use of explosives in or near Canadian fisheries waters. Canadian Technical Report of Fisheries and Aquatic Sciences 2107. Ottawa, Ontario: DFO. http://www.dfo-mpo.gc.ca/Library/232046.pdf

Yurkowski, D.J., Young, B.G., Dunn, B., and Ferguson, S.H. 2019. Spring distribution of ringed seals (Pusa hispida) in Eclipse Sound and Milne Inlet, Nunavut: Implications for potential ice-breaking activities. Arctic Science 5(1):54 - 31. https://doi.org/10.1139/as-2018-0020 